\title{
Influence of sugarcane bagasse variability on sugar recovery for cellulosic ethanol production
}

\author{
Liliane Pires Andrade ${ }^{\mathrm{a}, \mathrm{b}, *}$, Elaine Crespim ${ }^{\mathrm{c}}$, Nilton de Oliveira ${ }^{\mathrm{d}}$, Rafael Carinha de Campos ${ }^{\mathrm{d}}$, \\ Juliana Conceição Teodoro ${ }^{\mathrm{d}}$, Célia Maria Araújo Galvão ${ }^{\mathrm{d}}$, Rubens Maciel Filho ${ }^{\mathrm{a}}$ \\ ${ }^{a}$ University of Campinas (UNICAMP), School of Chemical Engineering, CEP 13083-970 Campinas, São Paulo, Brazil \\ ${ }^{\text {b }}$ São Paulo State University (UNESP), IBILCE, Laboratory of Biochemistry and Applied Microbiology, CEP 15054-000 São José do Rio Preto, São Paulo, Brazil \\ ' Independent Researcher, CEP 13425-020 Piracicaba, São Paulo, Brazil \\ ${ }^{\mathrm{d}}$ Sugarcane Technology Center (CTC), CEP 13400-160 Piracicaba, São Paulo, Brazil
}

\section{H I G H L I G H T S}

- Raw material variability influences glucose and xylose recovery.

- Glucose concentration is directly related to total solids.

- Glucan conversion is proportional to enzyme load.

- Ethanol production can vary up to 1.59 million L/year due to bagasse variability.

\section{A R T I C L E I N F O}

\section{Article history:}

Received 17 March 2017

Received in revised form 12 May 2017

Accepted 13 May 2017

Available online 18 May 2017

\section{Keywords:}

Raw material variability

Sugarcane bagasse

Cellulosic ethanol

Enzymatic hydrolysis

Steam explosion pretreatment

\begin{abstract}
A B S T R A C T
In the context of cellulosic ethanol production, special attention must be given to the raw material, as it affects final product yield. As observed for sugarcane, bagasse variations may derive from several elements, for instance edaphoclimatic factors, seasonality, maturation stage and harvesting techniques. Therefore, in the present work, to investigate the impact of raw material characteristics on process performance, sugarcane bagasse from four harvests from October/2010 to October/2011 was pretreated by steam explosion and had its soluble and insoluble solids contents measured, following enzymatic hydrolysis to assess glucan conversion. As confirmed by ANOVA, glucose concentration was related to the solids content in the reactor, whereas glucan conversion was related to the enzymatic load. Variations in raw material composition were indeed observed to significantly interfere in the final sugar recovery, probably due to the increase in the impurities observed as a result of the type of harvest performed in 2011.
\end{abstract}

(c) 2017 Elsevier Ltd. All rights reserved.

\section{Introduction}

In the current world scenery, the search for fuels and other chemicals developed from sustainable technologies has become an increasing demand as already pointed out by Sørensen et al. (2013). In this context, sugarcane bagasse, among several biomasses investigated worldwide, is considered in Brazil for use as raw-material for cellulosic ethanol production (Bezerra and Ragauskas, 2016; Rocha et al., 2015). In fact, the use of sugarcane bagasse as raw material for 2nd generation ethanol is potentially interesting since it is readily available in the 1st generation plants with the attractiveness to share process facilities and equipment

\footnotetext{
* Corresponding author at: Rua Cristóvão Colombo, 2265, CEP 15054-000 São José do Rio Preto, SP, Brazil.

E-mail address: lilianeandrade.eq@gmail.com (L.P. Andrade).
}

beyond administrative infrastructure with direct impact on the investments (Bezerra and Ragauskas, 2016; Sindhu et al., 2016). The 2nd generation process comprises basically the following steps: (1) biomass pretreatment (physical, chemical or physicochemical); (2) hydrolysis (acid or enzymatic) of the fractions cellulose and hemicellulose; (3) fermentation of the sugars produced in the previous steps; and (4) separation/purification of the ethanol produced (Alvira et al., 2010; Chiaramonti et al., 2012; Yang and Wyman, 2008).

Studies directed to cellulosic ethanol production have demonstrated that simultaneous alterations in important parameters, such as pretreatment time and method, as well as total solids in enzymatic hydrolysis, directly influence final process yield (Chiaramonti et al., 2012; Jia et al., 2015; Oliveira et al., 2014; Ramos et al., 2015; Singh et al., 2010; Yang and Wyman, 2008). Moreover, differences in raw material characteristics can lead to 
alterations in sugar recovery. In this sense, it is known that edaphoclimatic factors (soil and climate conditions), variety, maturation and seasonality, for instance, can influence sugarcane chemical and/or structural composition and, consequently, the composition of the bagasse formed after syrup extraction (Carvalho et al., 2016; Souza et al., 2005; Stupiello, 1987).

The expansion of the sugar and alcohol sector, which provides sugarcane bagasse and straw for lignocellulosic ethanol production in Brazil, brought numerous benefits for the country. On the other hand, a strong environmental impact emerged as a consequence of sugarcane straw burning for manual cropping, which led the State of São Paulo Government, together with UNICA (União da Indústria de Cana-de-açúcar, Brazilian Sugarcane Industry Association) to create, in 2007, the Protocol of AgroEnvironmental Cooperation, aiming at the complete elimination of sugarcane burning by 2017. Nevertheless, with the increase in crude sugarcane harvest and the sharp fall in burning since the harvest of 2010/11 (http://www.iea.sp.gov.br/Relat\%C3\% B3rioConsolidado1512.pdf), some of the plant components called vegetable and mineral impurities - which formerly stayed in the field after the burnings started to enter in higher amounts in the process (PAES, 2011).

The effects of this new reality's impact on sugar production have already been analyzed by Merheb et al. (2016), who studied the impact of sugarcane field remnants on the final process yield of sugar production. Furthermore, Paes (2011) investigated the problems related to the processing of mechanically harvested sugarcane by the Mills, among which: loses in crushing capacity and syrup extraction; increase in energy consumption for cane preparation; equipment wear (pumps, valves, millings and others); difficulty for syrup treatment and for the production of a good-quality sugar; reduction in fermentation yield; operational problems with the boiler; reduction in bulk density/increase in transportation cost etc. Such impacts must therefore be evaluated for cellulosic ethanol production.

Nevertheless, attempts to fix or isolate these variables to determine their real impact on the process of cellulosic ethanol production are often inaccurate. Therefore, the purpose of this work was to investigate how this process is influenced by the combination of the aforementioned variables, here called "raw material variability" (RMV). For this goal, sugarcane bagasse was collected in predefined periods in two consecutive crops which were subjected to a progressive rise in the harvest of crude cane, thus providing a variability in sugarcane chemical composition from the two periods. RMV impact on glucose release for the fermentative process was assessed by assays based on pretreatment and enzymatic hydrolysis.

\section{Materials and methods}

\subsection{Material}

All experiments were performed with sugarcane bagasse (SCB) as raw material, obtained from Iracema Mill, (Iracemápolis, SP, Brazil), with logistical support of the Sugarcane Technology Center (CTC - Piracicaba, SP, Brazil) technical staff. The mill is located in a low water-stress region, with the following textures observed in the dominant soil types: loamy (55\%), medium texture (25\%) and sandy texture (20\%). In this Mill, syrup extraction is performed by milling. SCB was collected in October/2010, May/2011, August/2011 and October/2011. For enzymatic hydrolysis, Cellic CTec2 cocktail was kindly provided by Novozymes ${ }^{\circledR}$ (Curitiba, PR, Brazil). The surfactant used was Tween ${ }^{\circledR} 20$ (Sigma-Aldrich). All reagents used were of analytical grade.

\subsection{Sugarcane bagasse pretreatment}

Pretreatment was conducted by steam explosion of $4 \mathrm{~kg}$-dry basis of SCB in a 65 L-reactor. SCB was fed into the reactor in the absence of catalysts, following injection of saturated steam until the operating temperature and pressure conditions were met (pressure at $17 \mathrm{kgf} / \mathrm{cm}^{2}$; $5 \mathrm{~min}$ ramp; $8 \mathrm{~min}$ plateau). Subsequently, the reactor content was abruptly decompressed into a cyclone for sample collection. The batches were produced and subjected to chemical and physicochemical analyses for full characterization. Structural Carbohydrates and lignin contents in the pretreated bagasse (PTB) and in SCB were determined according to Sluiter et al. (2008). Carbohydrate and furan analyses of all samples were performed by HPLC.

\subsection{Enzymatic hydrolysis of the pretreated bagasse}

PTB hydrolysis assays were performed for $48 \mathrm{~h}$ in a 2-L reactor (Fisatom 713) with 4 blades at $45^{\circ}$ for mechanical agitation. For all assays, final reaction volume was $500 \mathrm{~mL}$, including the water present in PTB. The conditions used for enzymatic hydrolysis are described in Table 1 as part of a Central Composite Rotatable Design (CCRD). The following variables were investigated in CCRD: total solids (TS), enzyme load (EL) and surfactant concentration (SC).

Hydrolysis was conducted in $100 \mathrm{mmol} \mathrm{L}^{-1}$ sodium citrate buffer $\mathrm{pH} 4.8$ at $50{ }^{\circ} \mathrm{C}$. To determine the volume of Cellic CTec2 used in each assay, enzymatic activity was determined according to Ghose (1987). Samples were taken for glucose release evaluation by HPLC after 24 and $48 \mathrm{~h}$. At the end of the reaction, the suspension was filtered to separate the residual cellulignin from the hydrolysate broth. Carbohydrate and furan analyses in all samples were performed by HPLC. Eq. (1) was used to calculate the conversion of glucans into monomeric glucose.

$\eta=\frac{M_{\text {Experimental Glucose }}-M_{\text {Blank }}}{M_{\text {Glucans }} * f} * 100 \%$

Equation 1. Calculation of glucan conversion into monomeric glucose. MExperimental Glucose, mass of glucose present in the hydrolysate; $\mathbf{M}_{\mathbf{B l a n k}}$, mass of glucose measured immediately before enzyme addition; $\mathbf{M}_{\mathbf{G l u c a n s}}$, the initial mass of glucans present in the fiber of the pretreated bagasse; $f$ is the conversion factor of glucan into glucose $(f=180 / 162=1.111)$.

Statistical analysis of the enzymatic hydrolysis CCRD was performed using the software STATISTICA 12.0, assessing the following variables: total solids (TS), enzyme load (EL) and surfactant concentration (SC). For this analysis, the responses evaluated were glucan conversion and glucose concentration after $48 \mathrm{~h}$.

\subsection{Analysis of carbohydrate and furan concentrations}

Glucose, cellobiose, fructose, arabinose and xylose were quantified in the hydrolysates and compositional analysis samples by high performance liquid chromatography (HPLC) from Waters using an Aminex HPX 87P column (BioRad), with Milli-Q water as eluent (mobile phase) using an oven temperature of $65^{\circ} \mathrm{C}$, $0.5 \mathrm{~mL} . \mathrm{min}-1$ flow for $30 \mathrm{~min}$, with a refractive index (RI) detector.

Furfural and hydroxymethylfurfural (HMF) were quantified in the hydrolysates and compositional analysis samples by HPLC as described above, using $0.005 \mathrm{M} \mathrm{H}_{2} \mathrm{SO}_{4}$ as eluent, with an operation flow of $0.6 \mathrm{~mL} . \mathrm{min}^{-1}$ and 50-min analysis time, using an UV detector (Waters 2489) with a $210 \mathrm{~nm}$ wavelength. 
Table 1

CCRD values used for the determination of total solids (TS), enzyme load (EL) and surfactant concentration (SC).

\begin{tabular}{|c|c|c|c|c|c|c|}
\hline Variables & Code & -1.68 & -1 & 0 & +1 & +1.68 \\
\hline TS (\%) & 1 & 8 & 8.81 & 10 & 11.19 & 12 \\
\hline EL (FPU. $\mathrm{g}^{-1}$ of glucan) & 2 & 4.32 & 5 & 6 & 7.00 & 7.68 \\
\hline SC (g. $g^{-1}$ of dry PTB) & 3 & 0 & 0.30 & 0.75 & 1.20 & 1.50 \\
\hline
\end{tabular}

Table 2

Compositional analysis of SCB and PTB by steam explosion based on the insoluble solids content (IS) and soluble solids content (SS).

\begin{tabular}{|c|c|c|c|c|c|c|c|c|c|c|}
\hline Sample & $\begin{array}{l}\text { Insoluble solids } \\
\text { (\% PTB) }\end{array}$ & $\begin{array}{l}\text { Glucan } \\
\text { (\% IS) }\end{array}$ & $\begin{array}{l}\text { Xylan } \\
(\% \text { IS })\end{array}$ & $\begin{array}{l}\text { Lignin } \\
\text { \% IS) }\end{array}$ & $\begin{array}{l}\text { Soluble solids } \\
\text { (\% PTB) }\end{array}$ & $\begin{array}{l}\text { Glucose } \\
(\% \mathrm{SS})\end{array}$ & $\begin{array}{l}\text { HMF } \\
(\% \mathrm{SS})\end{array}$ & $\begin{array}{l}\text { Xylose } \\
\text { (\% SS) }\end{array}$ & $\begin{array}{l}\text { Furfural } \\
(\% \mathrm{SS})\end{array}$ & $\begin{array}{l}\text { Acetic acid } \\
(\% \mathrm{SS})\end{array}$ \\
\hline SCB & - & $40.57 \pm 1.04$ & $25.09 \pm 0.79$ & $22.71 \pm 0.68$ & - & - & - & - & - & - \\
\hline РTB & $75.95 \pm 1.51$ & $58.32 \pm 2.33$ & $4.80 \pm 0.2$ & $31.64 \pm 1.22$ & $24.05 \pm 0.47$ & $10.84 \pm 0.28$ & $0.62 \pm 0.02$ & $58.48 \pm 2.32$ & $2.65 \pm 0.12$ & $13.93 \pm 0.69$ \\
\hline
\end{tabular}

\section{Results and discussion}

\subsection{Pretreatment}

A previously optimized condition for sugarcane bagasse pretreatment (Andrade et al., 2012) was employed. Both SCB and PTB were characterized (Table 2, compositional analysis).

The compositional analysis of the insoluble solids (IS) in SCB and PTB (Table 2) revealed significant differences in the amounts of glucan, xylan and lignin before and after pretreatment. The differences observed reflect mainly the major solubilization of hemicellulose after pretreatment, thus reducing the total mass of insoluble material, following a trend reported in literature (Biswas et al., 2014; Harrison et al., 2013; Neves et al., 2016; Rocha et al., 2012). It can therefore be stated that these are actually only relative - and not absolute - differences, once pretreatment does not change glucan and lignin amounts significantly.

The xylan portion was largely solubilized during pretreatment, as observed in Table 2 (soluble solids, SS). A part of it was effectively solubilized into xylose, in spite of the detection of degradation compounds, such as furfural and acetic acid. Degradation of the glucan portion into HMF was also observed, still dramatically less expressive than the one of xylan. Glucan recovery consisted of $94.44 \%$, essentially in the solid fraction.

\subsection{Optimization of the enzymatic hydrolysis of glucan}

To study the influence of sugarcane bagasse variability on sugar recovery for cellulosic ethanol production, it was necessary to determine a condition for the enzymatic hydrolysis, which was performed by CCRD. The operation limits of each variable were defined considering the techno-economic process; therefore, high concentrations of enzymes and surfactant were avoided. A high TS value is also desirable, but the capacity of reactors determined its limitation in CCRD. The efficiency of enzymatic hydrolysis was measured based on glucan conversion (Fig. 1) and glucose concentration in the hydrolysate (Fig. 2).

As observed in Fig. 1, the best result was achieved when the highest EL was employed, with TS and SC in the average value of the design. In an overview, the results corroborate with the literature when Cellic CTec 2 is used (Ramos et al., 2015; Resch et al., 2013; Sant'Ana da Silva et al., 2016), and conversions above $60 \%$ were obtained in most of the cases. Nonetheless, once there was a variation in TS in the assays, glucose concentration in the hydrolysate proved to be a more reliable basis for selecting the assay with the highest glucose amount to be released. Fig. 2 exhibits the data on glucose concentration for all of the conditions assayed.

An analysis of Fig. 2 reveals that glucose concentrations were around $35-40 \mathrm{~g} / \mathrm{L}$ and the experiments resulting in the highest

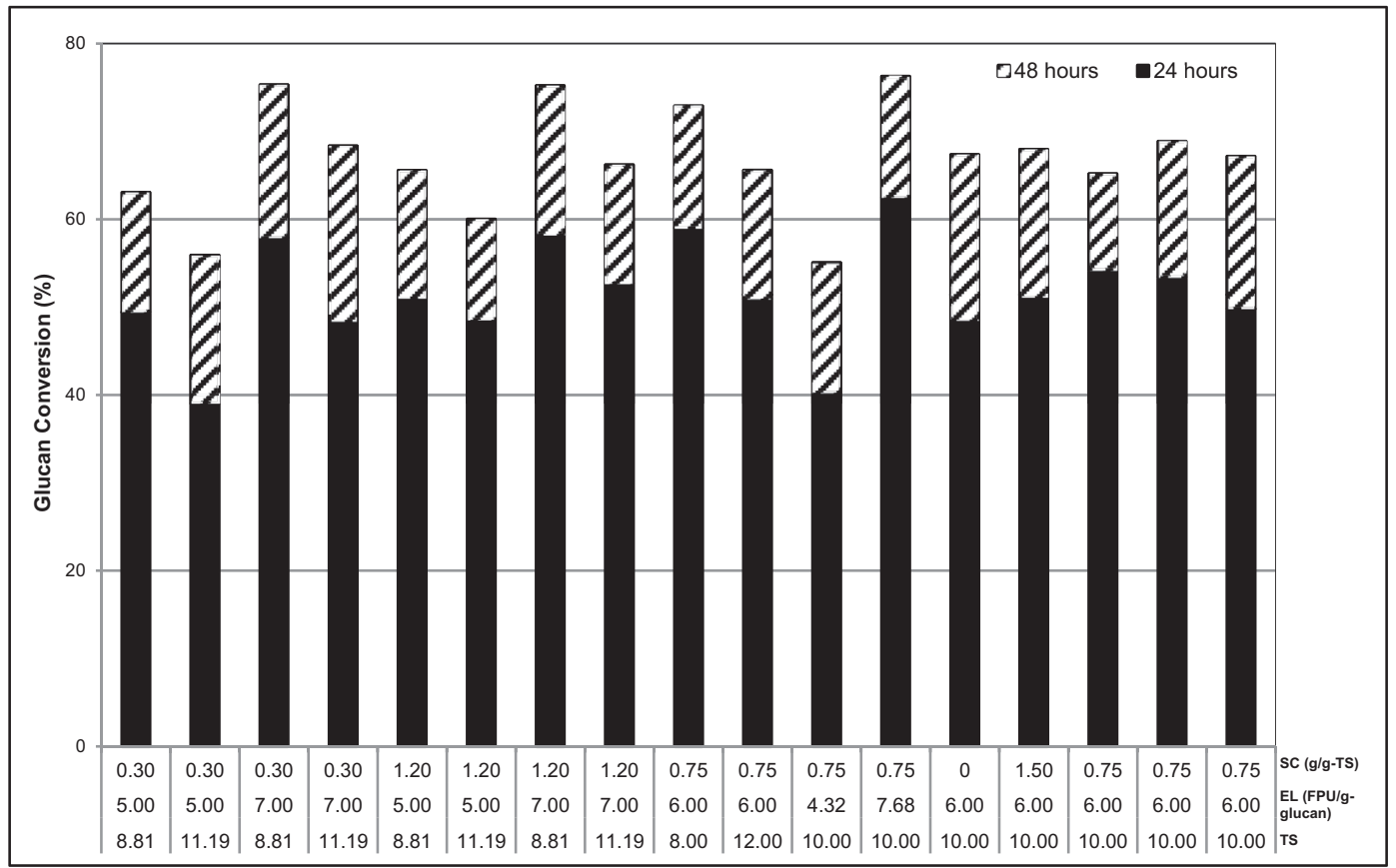

Fig. 1. Glucan conversion achieved after $48 \mathrm{~h}$ in CCRD enzymatic hydrolysis experiments, using Cellic CTec2. 


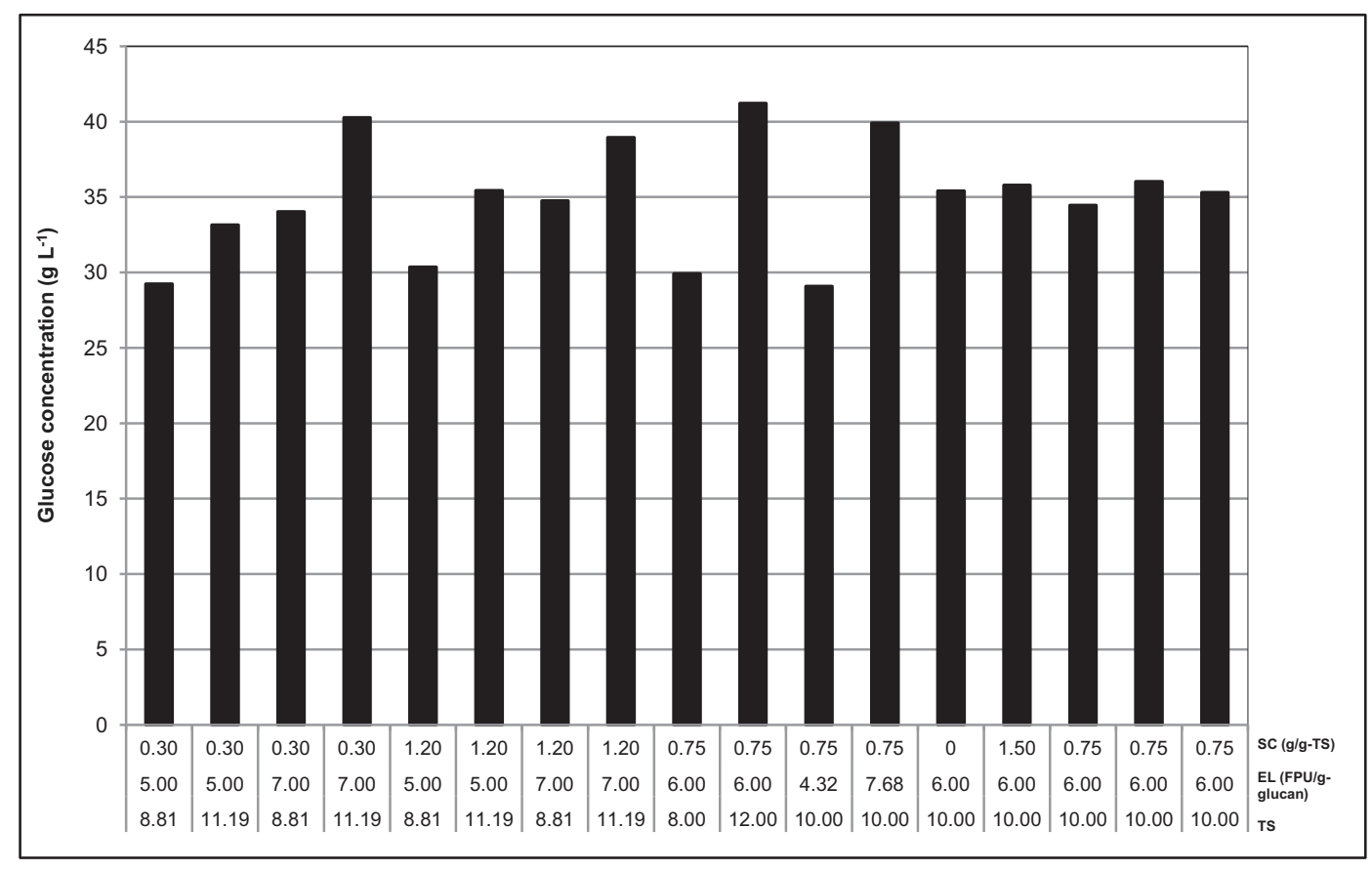

Fig. 2. Glucose concentrations achieved after $48 \mathrm{~h}$ in CCRD enzymatic hydrolysis experiments, using Cellic CTec2.

glucose concentrations were not necessarily the same with the highest conversions. It is noteworthy that glucose concentration in the assays is directly associated to TS in the reactor, whereas glucan conversion rates are more strictly related to EL. Therefore, these two responses were treated statistically (Eqs. (2) and (3)), considering the experimental data for $48 \mathrm{~h}$ of hydrolysis.

Glucan conversion $(\%)=66.81-3.01 * \mathrm{TS}+5.58 * \mathrm{EL}$

Glucose concentration $(\mathrm{g} / \mathrm{L})=34.89+2.82 * \mathrm{TS}+2.79 * \mathrm{EL}$

An important point to be considered in this work is the development of a process which combines glucose release with a low concentration of inhibitory compounds for fermentation. Such inhibitors can be divided into three main groups: organic acids, furan derivatives (furfural and HMF) and phenolic compounds. In the assays carried out in this work, values below $0.80 \mathrm{~g} / \mathrm{L}$ were detected for HMF and furfural, which does not result in a significant influence on fermentation (Teodoro et al., 2013). Conversely, from 3.38 to $5.20 \mathrm{~g} / \mathrm{L}$ of acetic acid was detected, an amount which, in turn, can hamper fermentation.

Table 3 presents the analysis of variance (ANOVA) of the mathematical model employed in this work, with the residues subdivided into "pure error" (experimental error of the process) and "lack of fit" (differences between the data generated by the model). The values were considered valid when the regression variance was superior to the tabulated F-value and residue variance was below its F-value within the confidence level of $90 \%$, thus consisting of a suitable linear model for enzymatic hydrolysis data adjustment, as confirmed by the present results. In the resulting models, for glucan conversion, the values of regression coefficient $\left(R^{2}\right)$ and maximum percentage of variance (\% Var) corresponded to 0.89948 and 0.91205 , respectively, while $\mathrm{R}^{2} 0.92779$ and \% Var 0.93682 were obtained for glucose concentration. The response surfaces for the models determined above are shown in Fig. 3, considering only the significant effects.

In Fig. 3-a, an inversely proportional relation is observed for variables TS and EL, with glucan conversion enhanced in high EL, but reduced in high TS values. Still, these variables are proportional to each other (Fig. 3-b), with an increase in glucose concentration in the hydrolysate observed for higher values of TS and EL. These results, therefore, support the observation that glucose concentration is related to the solids content in the reactor, whereas glucan conversion is more related to the enzymatic load; thus, these factors were considered parameters to determine the best condition for enzymatic hydrolysis.

SC was not statistically significant for the levels tested for both responses, which must have happened due the low concentration used in this study, in comparison to other studies that used around 5\% (w/w) (Eriksson et al., 2002; Han and Chen, 2010; Qing et al., 2010). Considering the process techno-economic viability, there is no need of adding this product in the process, once it does not promote a significant change in the final result.

To obtain a technically and economically viable condition using the response surface analysis, conditions were determined where glucose concentration and process yield were simultaneously elevated (TS $=12 \%$, EL 6 FPU/g-cel) and, as the surfactant did not present a significant influence in the level evaluated, it was not added, thus reducing process operational cost, OPEX.

The predicted and observed values obtained by the experimental validation assay were respectively 61.75 and $69.62 \%$ for glucan conversion and 39.63 and $42.30 \%$ for glucose concentration. The models consist of only the statistically significant parameters. For glucose concentration, the main response variable, model prediction deviation is inside the stipulated value, $\mathrm{p}$-value $<0.10$; which validates this model. These prediction errors are probably due to the simplicity of the statistical models. Despite the deviations when the experimental and predicted results are compared, the data obtained in the validation assay can be considered satisfactory in the context of bioprocess.

\subsection{Analysis of raw material variability influence on the ethanol production process}

Many variables can influence the quality of raw material for cellulosic ethanol production, among which process conditions (pre- 
Table 3

Analysis of variance (ANOVA) of the Central Composite Rotatable Design regarding glucan conversion and glucose concentration.

\begin{tabular}{|c|c|c|c|c|c|c|}
\hline Response & Source & $\mathrm{SS}^{1}$ & $\mathrm{DF}^{2}$ & $\mathrm{MS}^{3}$ & $\mathrm{~F}^{4}$ & $\mathrm{~F}_{\text {table }}$ \\
\hline \multirow[t]{5}{*}{ Glucan conversion } & Regression & 548.18 & 2 & 274.09 & 72.59 & 2.18 \\
\hline & Residual & 52.86 & 14 & 3.78 & & \\
\hline & Lack of fit & 46.08 & 12 & 3.84 & 1.13 & 6.07 \\
\hline & Pure error & 6.79 & 2 & 3.39 & & \\
\hline & Total & 601.05 & 16 & & & \\
\hline \multirow[t]{5}{*}{ Glucose concentration } & Regression & 214.09 & 2 & 107.05 & 103.79 & 2.18 \\
\hline & Residual & 14.44 & 14 & 1.03 & & \\
\hline & Lack of fit & 13.20 & 12 & 1.10 & 1.78 & 6.07 \\
\hline & Pure error & 1.24 & 2 & 0.62 & & \\
\hline & Total & 228.53 & 16 & & & \\
\hline
\end{tabular}

\footnotetext{
$1 \mathrm{SS}=$ sum of squares.

$2 \mathrm{DF}=$ degrees of freedom.

$3 \mathrm{MS}=$ mean square.

$\mathrm{F}=$ variance.
}

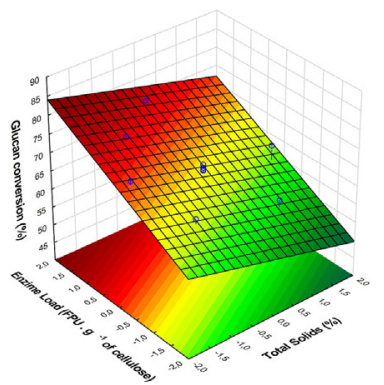

(a)

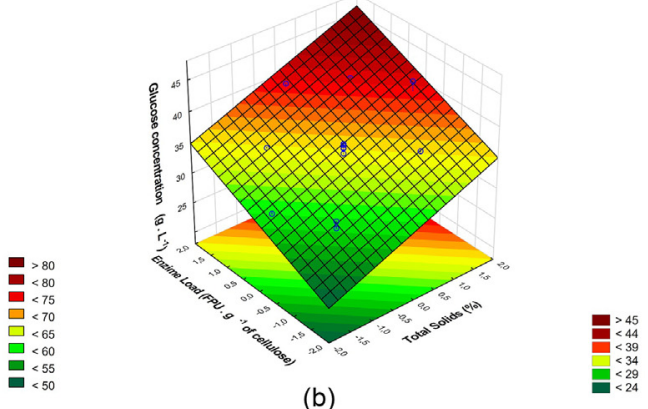

(b)

Fig. 3. Response surface in relation to TS and EL for (a) glucan conversion and (b) glucose concentration.

treatment and enzymatic hydrolysis). These were used in this work to evaluate the variability of the raw material studied. As described in items 3.1.1 and 3.1.2., pretreatment was performed at $17 \mathrm{kgf} /$ $\mathrm{cm}^{2}$, ramp time of $5 \mathrm{~min}$ and plateau time of $8 \mathrm{~min}$, and enzymatic hydrolysis with $12 \%$ of solids and $6 \mathrm{FPU} / \mathrm{g}$-glucan. Sugarcane bagasse (SCB) composition was firstly determined for the four harvests in terms of glucan, xylan, lignin and ash percentages present in the fiber (Table 4).

As observed in Table 4, small differences were registered for glucan and lignin considering the four harvests. The mean value calculated for glucan was $40.52 \%$ and for lignin, $21.05 \%$. For xylans, on the other hand, a higher variation was observed between samplings made in May and August/2011 - 28.12\% and 21.87\%, respectively. Xylan percentages for both harvests in October stayed near the total mean value, $24.89 \%$.

The amount of ash has a direct relationship with impurities present in SCB and reveals its increase along the harvests in 2011, with the highest numbers in October 2010 deriving from the rainy period. The standard deviations were all lower than $5 \%$, which supports analysis reliability. For all components, the values are inside the range determined for sugarcane bagasse, as stated by Antonio Bizzo et al. (2014).
Regarding the composition of the pretreated bagasse samples (Table 5), in 2011, after the pretreatment the differences among the harvests were reduced; glucan, xylan and lignin in the solid fraction of PTB also had small deviations of $1.22 \%, 0.49 \%$ and $1.25 \%$ in the values, respectively. The standard deviations were all around 5\%, which shows the analysis reliability. In relation to the PTB from October 2010, glucan and lignin amounts decreased, whereas xylan increased. This difference might be related to the higher amount of mineral impurities in the bagasse (Table 4), because of a higher extent of crude sugarcane processed by the Mill due to the Protocol of Agro-Environmental Cooperation. A higher amount of mineral impurities, such as silica, induces a rise in biomass buffering capacity, limiting the effect of the acetic acid generated during the pretreatment (autocatalytic), eventually leading to a reduction in xylan solubilization in the process (Claramunt et al., 2011).

Analyzing the compounds solubilized during pretreatment (Table 5), it is observed that a great part of xylan was solubilized during pretreatment, with a lower solubilization observed throughout 2011 in relation to October 2010 in approximately $25 \%$. These results support the higher percentage of xylan present in the fiber for this same period, as shown in Table 4. Some

Table 4

Compositional analysis of SCB for all harvests.

\begin{tabular}{|c|c|c|c|c|}
\hline Sample & Glucan (\%) & Xylan (\%) & Lignin (\%) & Ash (\%) \\
\hline Oct $/ 10$ & $40.57 \pm 1.04$ & $25.09 \pm 0.79$ & $22.71 \pm 0.68$ & $7.13 \pm 0.36$ \\
\hline May/11 & $40.62 \pm 1.13$ & $28.12 \pm 0.84$ & $21.25 \pm 0.73$ & $6.97 \pm 0.31$ \\
\hline Aug/11 & $41.51 \pm 0.94$ & $21.87 \pm 0.63$ & $20.65 \pm 0.65$ & $8.65 \pm 0.39$ \\
\hline Oct/11 & $39.38 \pm 0.98$ & $24.51 \pm 0.74$ & $19.58 \pm 0.77$ & $9.48 \pm 0.42$ \\
\hline
\end{tabular}


Table 5

Compositional analysis of the bagasse samples pretreated by steam explosion in pilot scale based on the insoluble solids content (IS) and soluble solids content (SS).

\begin{tabular}{|c|c|c|c|c|c|c|c|c|c|c|}
\hline Sample & $\begin{array}{l}\text { Insoluble solids } \\
\text { (\% РTB) }\end{array}$ & $\begin{array}{l}\text { Glucan } \\
\text { (\% IS) }\end{array}$ & $\begin{array}{l}\text { Xylan } \\
(\% \text { IS })\end{array}$ & $\begin{array}{l}\text { Lignin } \\
\text { (\% IS) }\end{array}$ & $\begin{array}{l}\text { Soluble solids } \\
\text { (\% PTB) }\end{array}$ & $\begin{array}{l}\text { Glucose } \\
(\% \mathrm{SS})\end{array}$ & $\begin{array}{l}\mathrm{HMF} \\
(\% \mathrm{SS})\end{array}$ & $\begin{array}{l}\text { Xylose } \\
(\% \text { SS) }\end{array}$ & $\begin{array}{l}\text { Furfural } \\
(\% \mathrm{SS})\end{array}$ & $\begin{array}{l}\text { Acetic acid } \\
(\% \mathrm{SS})\end{array}$ \\
\hline BPT (Oct/10) & $75.95 \pm 1.51$ & $58.32 \pm 2.33$ & $4.80 \pm 0.2$ & $31.64 \pm 1.22$ & $24.05 \pm 0.47$ & $10.84 \pm 0.28$ & $0.62 \pm 0.02$ & $58.48 \pm 2.32$ & $2.65 \pm 0.12$ & $13.93 \pm 0.69$ \\
\hline BPT (May/11) & $78.29 \pm 1.40$ & $52.63 \pm 1.67$ & $7.01 \pm 0.14$ & $30.66 \pm 0.92$ & $21.71 \pm 0.39$ & $9.15 \pm 0.29$ & $1.67 \pm 0.07$ & $46.35 \pm 1.64$ & $1.85 \pm 0.08$ & $13.62 \pm 0.58$ \\
\hline BPT (Aug/11) & $77.20 \pm 1.64$ & $52.73 \pm 1.56$ & $6.18 \pm 0.13$ & $28.16 \pm 0.80$ & $22.80 \pm 0.49$ & $8.09 \pm 0.34$ & $3.87 \pm 0.16$ & $45.79 \pm 1.43$ & $1.57 \pm 0.07$ & $12.84 \pm 0.61$ \\
\hline BPT (Oct/11) & $77.74 \pm 1.77$ & $50.59 \pm 1.39$ & $6.16 \pm 0.15$ & $29.30 \pm 0.92$ & $22.26 \pm 0.51$ & $9.95 \pm 0.41$ & $4.58 \pm 0.20$ & $37.39 \pm 1.41$ & $2.80 \pm 0.12$ & $14.98 \pm 0.75$ \\
\hline
\end{tabular}

products of degradation, namely furfural, HMF and acetic acid, were also detected, however in relatively low amounts.

The mass balance calculated for glucan (Fig. 4) and xylan (Fig. 5) allowed the evaluation of recovery/degradation of these sugars after pretreatment in the four sampling periods, indicating the degree of modification of these fractions. It is important to highlight that some degradation products might be volatilized during the steam explosion pretreatment operated in batch, depending mainly on the severity applied. For this reason, mass balances cannot be performed with a high precision, especially for xylan.

In the balances presented in Fig. 4, no significant differences were identified in glucan recovery for the sampling periods evaluated. The mean value for soluble glucose recovery (counting both mono- and oligosaccharide fractions) was $4.17 \%( \pm 0.47 \%)$ and the value for glucan in the fiber was $88.88 \%( \pm 2.02 \%)$. The values obtained along the crops were satisfactory, as approximately $90 \%$ of glucan was preserved and can be used for the generation of cellulosic ethanol.

The mean value calculated for soluble xylose recovery (Fig. 5) for the whole period of study was $33.19 \%$ ( $\pm 7.54 \%$ ). For xylan, the mean value reached $16.25 \%$ ( $\pm 3.40 \%)$. In other words, all crops preserved approximately $50 \%$ of the xylan present in SCB during pretreatment.

The deviation observed in Fig. 5 for May and August 2011 is due to xylan variation in SCB, since the data presented in Table 5 were homogeneous for the results obtained in the harvests performed in 2011. This result has a direct correlation with the differences detected in SCB xylan composition (Table 4), which interferes in the comparison of this fraction recovery with time, once in May the denominator was higher, therefore a lower recovery was obtained. The opposite behavior was observed for the sample collected in August 2011.

Regarding enzymatic hydrolysis (Fig. 6), the mean value observed for glucan conversion was $73.59 \%( \pm 2.21 \%)$, with a mean of $39.95 \mathrm{~g} \mathrm{~L}^{-1}( \pm 1.40 \%)$ for glucose concentration in the hydrolysate. As glucose concentration has a direct relation to ethanol production, when glucose consumption in alcoholic fermentation is

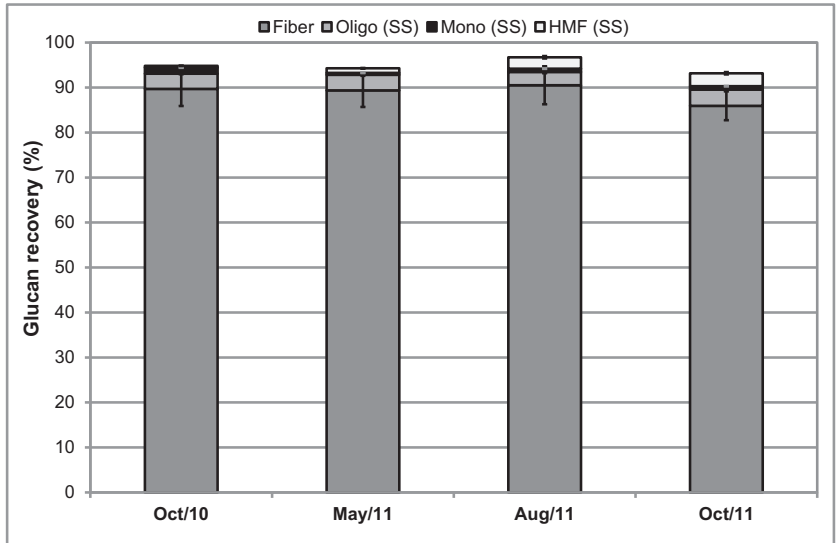

Fig. 4. Mass balance for glucan after pretreatment in pilot scale.

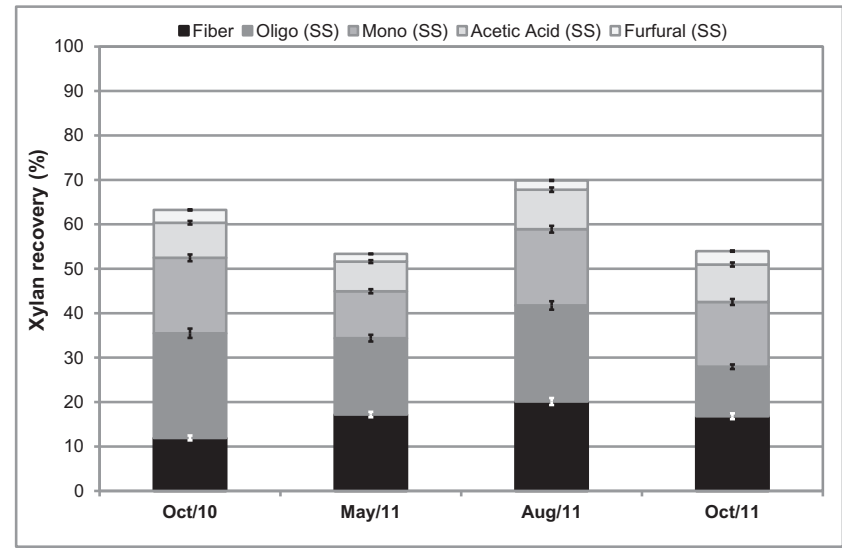

Fig. 5. Mass balance for xylan after pretreatment in pilot scale.

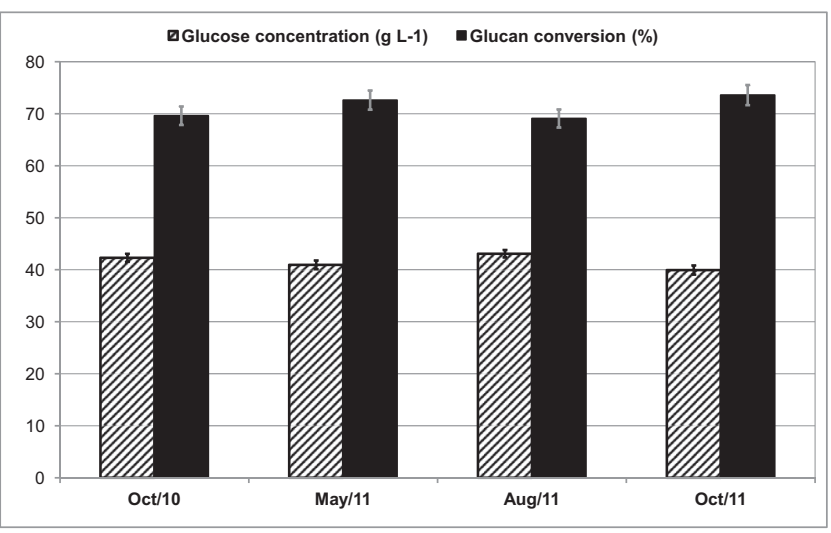

Fig. 6. Glucan conversions and glucose concentrations obtained in the enzymatic hydrolysis experiments to determine raw material variability.

considered, the deviation observed for glucose concentration might seem small; nonetheless, when this sugar is transformed into ethanol and the production capacity is considered for the main active production plants of cellulosic ethanol described by Bossle (2016), variations in ethanol production will be obtained, from 560,000 L/year (Raízen) to 1.59 million L/year (Dupont). This means that scaling up shows the expressivity of this deviation and the effect that seasonality in the sampling period analyzed has on the composition of the hydrolysate obtained and, therefore, in cellulosic ethanol production.

Since processes must not suffer significant influences in final yield when variations in the raw material are detected, the result of the present work confirms that raw material variability has a considerable influence not only on the final result (the composition of the hydrolysate obtained), but also in the intermediary step, PTB acquisition. As this is an initial and novel study, it is necessary to better understand how this variability happens and define process conditions which reduce the impact of this variable on cellulosic ethanol acquisition. 


\section{Conclusions}

The pretreatment employed was efficient for glucan and xylan recovery, with low release of inhibitors. Statistical analysis of the enzymatic hydrolysis revealed that glucose concentration is directly related to TS in the reactor, whereas glucan conversion is proportional to EL. Finally, variations in process input (SCB composition) were observed to interfere both in pretreatment, reducing xylan solubilization because of a higher amount of mineral impurities from the rise in crude cane processing, and in hydrolysate acquisition by enzymatic hydrolysis, where a deviation of $1.4 \%$ was observed, which can generate a variation in cellulosic ethanol production of until 1.59 million L/year.

\section{Acknowledgements}

The authors are grateful to Sugarcane Technology Center Centro de Tecnologia Canavieira (CTC) (Piracicaba, SP, Brazil) for providing laboratory and financial support to this work, to Novozymes Latin America (Araucaria, PR, Brazil) by the enzyme donation and to Iracema Mill by the supply of sugarcane bagasse.

\section{References}

Alvira, P., Tomás-Pejó, E., Ballesteros, M., Negro, M.J., 2010. Pretreatment technologies for an efficient bioethanol production process based on enzymatic hydrolysis: a review. Bioresour. Technol. 101, 4851-4861.

Andrade, L.P., Teodoro, J.C., Tomé, J.A.T.R., Galvão, C.M.A., Maciel, R., 2012. Avaliação da influência de parâmetros de pré-tratamento por explosão a vapor e hidrólise enzimática na produção de etanol a partir de bagaço de cana. In: COBEQ. pp. 1 9.

Antonio Bizzo, W., Lenço, P.C., Carvalho, D.J., Veiga, J.P.S., 2014. The generation of residual biomass during the production of bio-ethanol from sugarcane, its characterization and its use in energy production. Renew. Sustain. Energy Rev. 29, 589-603.

Bezerra, T.L., Ragauskas, A.J., 2016. A review of sugarcane bagasse for secondgeneration bioethanol and biopower production. Biofuels Bioprod. Biorefin. 6 246-256.

Biswas, R., Uellendahl, H., Ahring, B.K., 2014. Wet explosion pretreatment of sugarcane bagasse for enhanced enzymatic hydrolysis. Biomass Bioenergy 61 $104-113$.

Bossle, R. 2016. A situação do etanol celulósico é crítica, mas todos concordam que ela também é temporária. Mas conseguirá o etanol celulósico atingir um ponto sem volta antes que os investidores percam a disposição financeira para suportar o desenvolvimento da tecnologia? <https://www.novacana.com/n etanol/2-geracao-celulose/custo-producao-etanol-celulosico-usinas-mundo150316/> (accessed October 8th 2016).

Carvalho, J.L.N., Nogueirol, R.C., Menandro, L.M.S., Bordonal, R.de O., Borges, C.D., Cantarella, H., Franco, H.C.J., 2016. Agronomic and environmental implications of sugarcane straw removal: a major review. GCB Bioenergy, 1-16.

Chiaramonti, D., Prussi, M., Ferrero, S., Oriani, L., Ottonello, P., Torre, P., Cherchi, F., 2012. Review of pretreatment processes for lignocellulosic ethanol production, and development of an innovative method. Biomass Bioenergy 46, 25-35.

Claramunt, J., Ardanuy, M., García-Hortal, J.A., Filho, R.D.T., 2011. The hornification of vegetable fibers to improve the durability of cement mortar composites. Cem. Concr. Compos. 33, 586-595.

Eriksson, T., Börjesson, J., Tjerneld, F., 2002. Mechanism of surfactant effect in enzymatic hydrolysis of lignocellulose. Enzyme Microb. Technol. 31, 353-364.
Ghose, T.K., 1987. Measurement of cellulase activities. Pure Appl. Chem. 59, 695702.

Han, Y., Chen, H., 2010. Synergism between hydrophobic proteins of corn stover and cellulase in lignocellulose hydrolysis. Biochem. Eng. J. 48, 218-224.

Harrison, M.D., Zhang, Z., Shand, K., O’Hara, I.M., Doherty, W.O.S., Dale, J.L., 2013. Effect of pretreatment on saccharification of sugarcane bagasse by complex and simple enzyme mixtures. Bioresour. Technol. 148, 105-113.

Jia, L., Gonçalves, G.A.L., Takasugi, Y., Mori, Y., Noda, S., Tanaka, T., Ichinose, H., Kamiya, N., 2015. Effect of pretreatment methods on the synergism of cellulase and xylanase during the hydrolysis of bagasse. Bioresour. Technol. 185, 158164.

Merheb, G.de A., de Oliveira, N., Giulietti, M., Bernardo, A., 2016. Combined effect of starch and dextran in sucrose crystallization. Sugar Ind. 141, 697-704.

Neves, P.V., Pitarelo, A.P., Ramos, L.P., 2016. Production of cellulosic ethanol from sugarcane bagasse by steam explosion: effect of extractives content, acid catalysis and different fermentation technologies. Bioresour. Technol. 208, 184194.

Oliveira, C.M., Cruz, A.J.G., Costa, C.B.B., 2014. Improving second generation bioethanol production in sugarcane biorefineries through energy integration. Appl. Therm. Eng. 19, 819-827.

Paes, L.A.D., 2011. Impurezas e Qualidade de cana-de-açúcar. <http://stab.org.br/ impurezas/Luiz.pdf> (accessed on October 10th 2016).

Qing, Q., Yang, B., Wyman, C.E., 2010. Impact of surfactants on pretreatment of corn stover. Bioresour. Technol. 101, 5941-5951.

Ramos, L.P., da Silva, L., Ballem, A.C., Pitarelo, A.P., Chiarello, L.M., Silveira, M.H.L., 2015. Enzymatic hydrolysis of steam-exploded sugarcane bagasse using high total solids and low enzyme loadings. Bioresour. Technol. 175, 195-202.

Resch, M.G., Donohoe, B.S., Baker, J.O., Decker, S.R., Bayer, E.A., Beckham De, G.T., Himmel, M.E., 2013. Fungal cellulases and complexed cellulosomal enzymes exhibit synergistic mechanisms in cellulose deconstruction. Energy Environ. Sci. 6, 1858-1867. This J. is ${ }^{\text {a }}$ R. Soc. Chem..

Rocha, G.J.M., Gonçalves, A.R., Nakanishi, S.C., Nascimento, V.M., Silva, V.F.N., 2015. Pilot scale steam explosion and diluted sulfuric acid pretreatments: comparative study aiming the sugarcane bagasse saccharification. Ind. Crops Prod. 74, 810-816.

Rocha, G.J.M., Gonçalves, A.R., Oliveira, B.R., Olivares, E.G., Rossell, C.E.V., 2012 Steam explosion pretreatment reproduction and alkaline delignification reactions performed on a pilot scale with sugarcane bagasse for bioethanol production. Ind. Crops Prod. 35, 274-279.

Sant'Ana da Silva, A. Fernandes de Souza, M., Ballesteros, I. Manzanares, P. Ballesteros, M., Bon, E.P.S., 2016. High-solids content enzymatic hydrolysis of hydrothermally pretreated sugarcane bagasse using a laboratory-made enzyme blend and commercial preparations. Process Biochem. 51, 1561-1567.

Sindhu, R., Gnansounou, E., Binod, P., Pandey, A., 2016. Bioconversion of sugarcane crop residue for value added products - an overview. Renew. Energy 98, 203215.

Singh, A., Pant, D., Korres, N.E., Nizami, A.-S., Prasad, S., Murphy, J.D., 2010. Key issues in life cycle assessment of ethanol production from lignocellulosic biomass: challenges and perspectives. Bioresour. Technol. 101, 5003-5012.

Sluiter, A., Hames, B., Ruiz, R., Scarlata, C., Sluiter, J., Templeton, D., Nrel, D.C., 2008. Determination of structural carbohydrates and lignin in biomass determination of structural carbohydrates and lignin in biomass.

Sørensen, A., Lübeck, M., Lübeck, P.S., Ahring, B.K., 2013. Fungal beta-glucosidases: a bottleneck in industrial use of lignocellulosic materials. Biomolecules 3, 612631.

de Souza, Z.M., Paixão, A.C.S., Prado, R.de M., Cesarin, L.G., de Souza, S.R., 2005. Manejo de palhada de cana colhida sem queima, produtividade do canavial e qualidade do caldo. Ciênc. Rural 35, 1062-1068.

Stupiello, J.P., 1987. A cana como matéria-prima. In: Paranhos, S.B. (Ed.), Cana-deaçúcar: cultivo e utilização, 2. Fund. Cargill, Campinas, pp. 761-804.

Teodoro, J.C., Tomé, J.A.T.R., Andrade, L.P., Galvão, C.M.A., 2013. Avaliação do efeito dos inibidores presentes no caldo hidrolisado na fermentação utilizando a cepa SA1. In: Sinaferm. pp. 1-4.

Yang, B., Wyman, C.E., 2008. Pretreatment: the key to unlocking low-cost cellulosic ethanol. Biofuels Bioprod. Biorefin. 2, 26-40. 